\title{
Association between Resilience and Professional Quality of Life among Nurses Working in Intensive Care Units
}

\author{
Neda Gerami Nejad ${ }^{1}$, Mahdi Hosseini ${ }^{2}$, Seyed Mohammad Mousavi Mirzaei ${ }^{3}$, Zahra \\ Ghorbani Moghaddam ${ }^{4}$
}

\begin{abstract}
Background \& Aims: The frequent exposure of nurses to the painful conditions of patients in intensive care units (ICUs) could decrease their professional quality of life, thereby leading to mental issues, such as the declined quality of patient care and other consequences. Given the importance of resilience in difficult situations, the present study aimed to determine the association of resilience with the professional quality of life of ICU nurses.

Materials \& Methods: This descriptive-correlational study was conducted on 200 nurses working in the ICUs of the teaching hospitals affiliated to Birjand University of Medical Sciences in South Khorasan province, Iran in 2018. The participants were selected via census sampling. Data were collected using Connor-Davidson resilience questionnaire and Stamm professional quality of life scale. Data analysis was performed in SPSS version 16 using descriptive and inferential statistics, including t-test, analysis of variance (ANOVA), and Kruskal-Wallis test.

Results: The mean total score of resilience was $60.31 \pm 20.39$. As for the three dimensions of the quality of professional life, the mean score of compassion fatigue was $34.54 \pm 9.13$, the mean score of job burnout was $24.06 \pm 5.70$, and the mean score of secondary trauma was $26.49 \pm 7.86$. Moreover, an inverse, significant correlation was observed between resilience and compassion fatigue ( $\mathrm{r}=-0.44 ; \mathrm{P}=0.001)$.

Conclusion: Considering the average level of the professional quality of life in the nurses, special attention must be paid to the influential factors in professional quality of life. In addition, due to the significant association between resilience and compassion fatigue, incorporating resilience-promoting strategies into the nursing curriculum is recommended.
\end{abstract}

Keywords: Resilience, Professional Quality of Life, Nurse, Intensive Care Unit

\section{Conflict of Interest: No}

How to Cite: Gerami Nejad N, Hosseini M, Mousavi Mirzaei SM, Ghorbani Moghaddam Z. Association between Resilience and Professional Quality of Life among Nurses Working in Intensive Care Units. Iran Journal of Nursing. 2019; 31(116):49-60.

Received: 17 Nov 2018

Accepted: 16 Feb 2019

\footnotetext{
1. Lecturer, Department of Anesthesia, School of Paramedicine, Arak University of Medical Sciences, Arak, Iran

${ }^{2}$. Lecturer, Department of Medical-Surgical Nursing, School of Nursing \& Midwifery, East Nursing and Midwifery Research Center, Birjand University of Medical Sciences, Birjand, Iran

${ }^{3}$. Assistant Professor, Department of Neurology, School of Medicine, Medical Toxicology and Drug Abuse Research Center (MTDRC), Birjand University of Medical Sciences, Birjand, Iran

4. MS Student in Nursing, School of Nursing \& Midwifery, East Nursing and Midwifery Research Center, Birjand University of Medical Sciences, Birjand, Iran. (*Corresponding author) Tel: $09158659751 \quad$ Email:
} mahdi.hosseini@bums.ac.ir 


\title{
ارتباط تاب آورى با كيفيت زندكى حرفهاى در برستاران بخشهاى ويزٌه
}

\author{
ندا كَامى نزاد'، مهدى حسينى '، سيد محمد موسوى ميرزايى ‘ّ، *زهرا قربانى مقدمع
}

\section{جكيده}

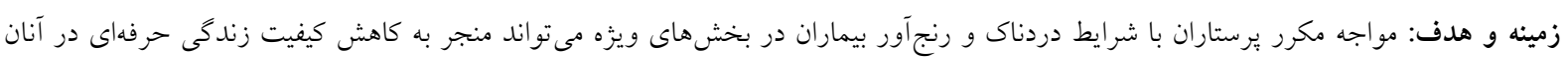

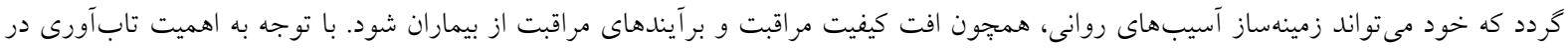

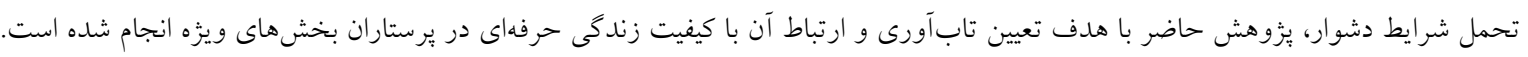

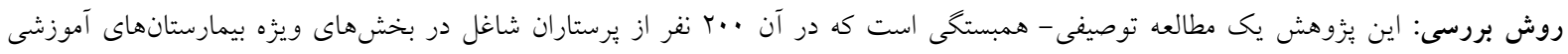

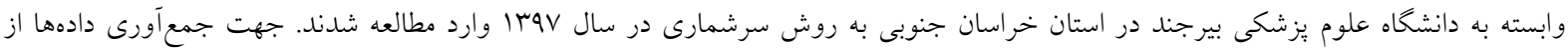

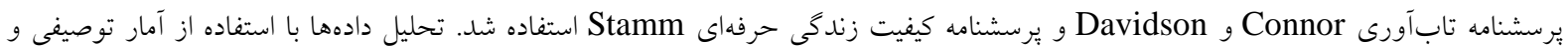
استنباطى شامل (تى تست، آناليز واريانس و كروسكالو اليس) در و

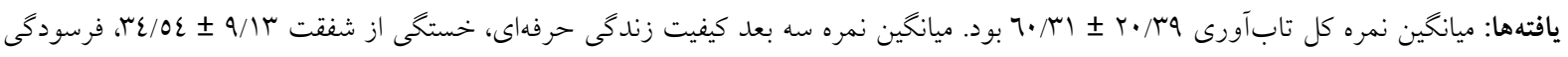

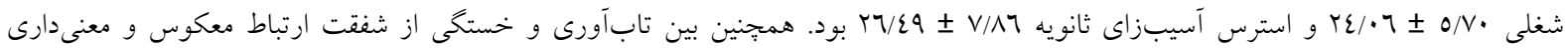
مشاهده شد (2)

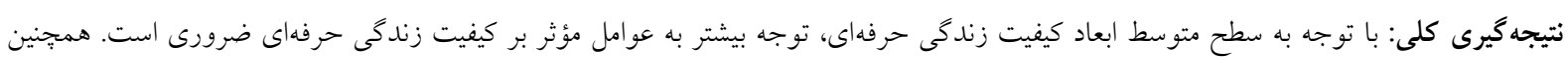

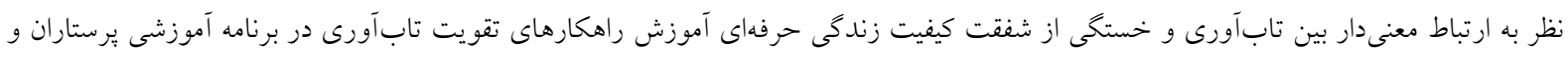
دانشجويان برستارى توصيه مىشود.

كليد وازهها: تابآورى، كيفيت زندگى حرفهاى، برستار، بخش مراقبت ويزّه تعارض منافع: ندارد تاريخ دريافت: 9V/N/T7 تاريخ بذيرش: TV/II/TV

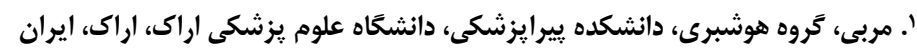

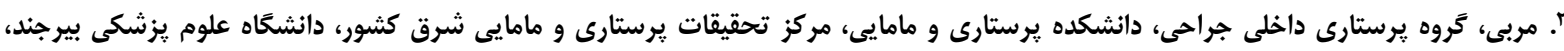
بيرجند، ايران

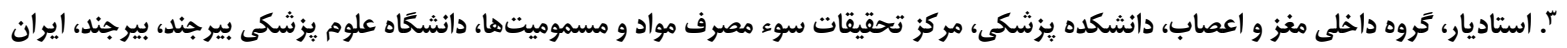

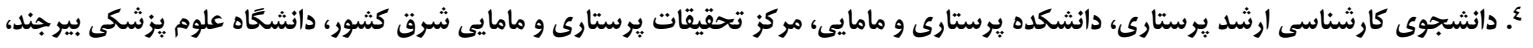


استرس آسيبزاى ثانويه يك احساس منفى است كه در

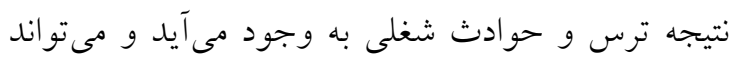

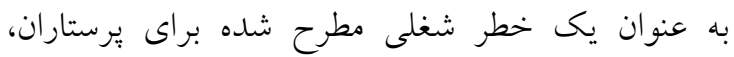

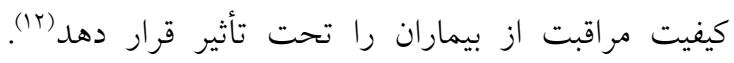

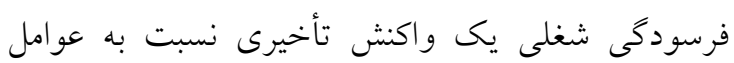
مزمن تنشزاى محيط كار است كه در مطالعات مختلف

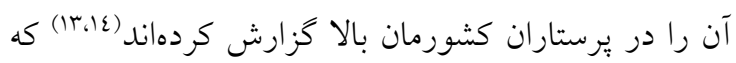
منجر به مشكلات جسمى و روانى و بيامدهايى نظير از

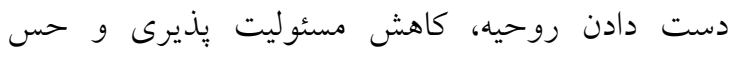
همكارى و در نهايت منجر به افت بازدهى در سازمان مى

كيفيت زندكى حرفهاى به طور همزمان به دنبال دو هدف لهو اصلى مىباشد؛ اول بهبود بهره ورى و كارايى كل سازمان،

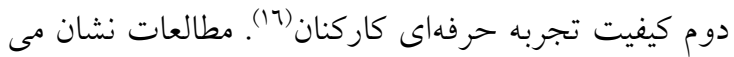
دهند كه با افزايش كيفيت زندكى حرفهاى هويت دوريت

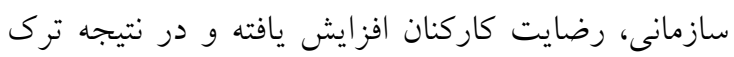

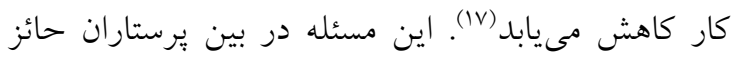

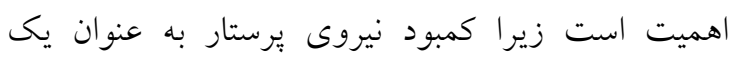

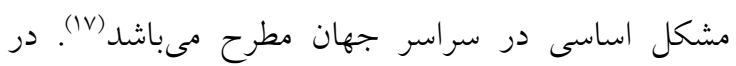

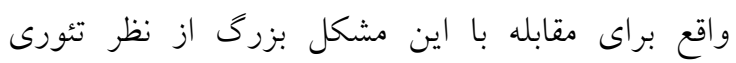

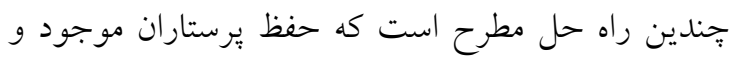

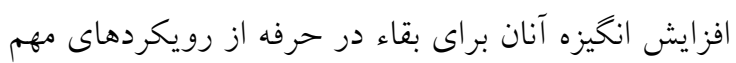

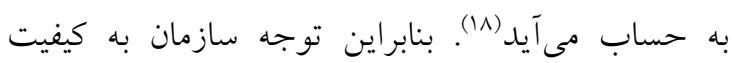

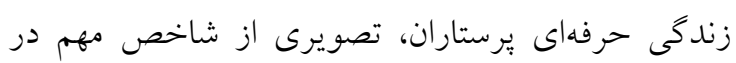

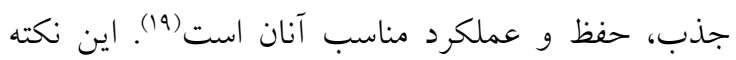
در برستاران بخشهاى ويزه از اهميت به خصوصى برخوردار است زيرا اين برستاران به دليل شرايط خاص ناشى از محيط كار و بيماران ممكن است استرس بيشترى را تجربه كنند (r.). از عوامل تنشزاى بخشهاى ويزٔه مى

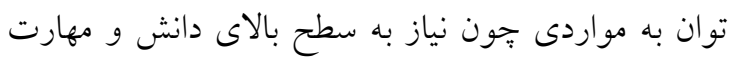
براى كار در اين بخشهاو حجم حرفهاى بالا، لزوم ياسخ

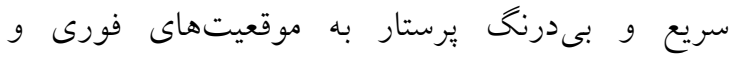
مسئوليت سنخين ناشى از مراقبت بيمار اشاره كرد(II).

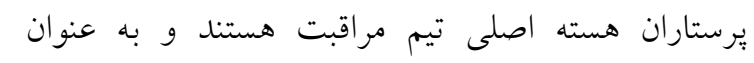

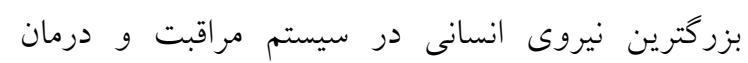

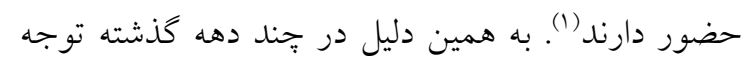

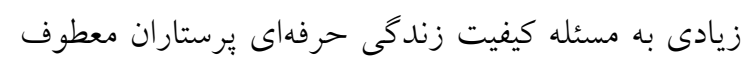

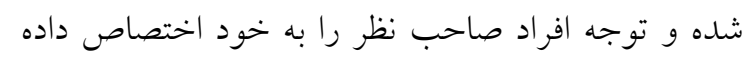

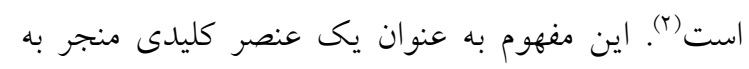

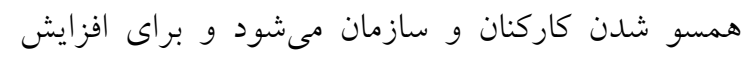

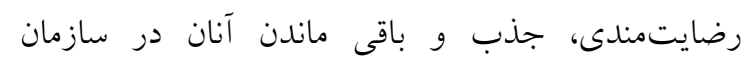
ضرورى است (r) و در نظام سلامت و در در ميان مراقبين

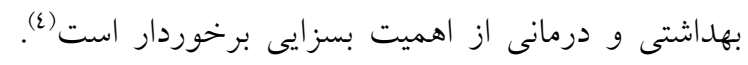

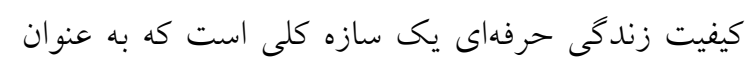
كيفيت احساس شخص در ارتباط با كارش به عنوان يك

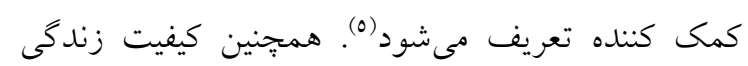

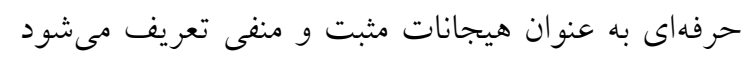
كه فرد درباره عملكردش به عنوان يك كمك كننده

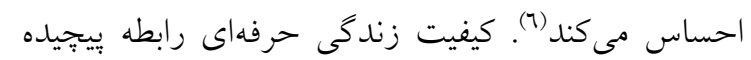

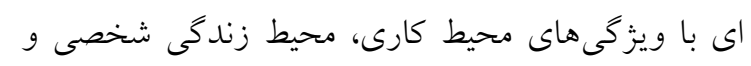

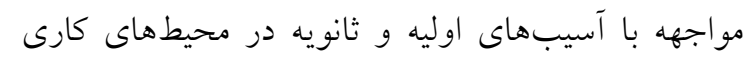

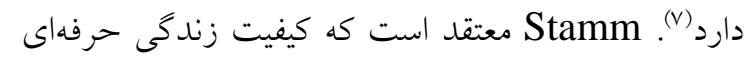
شامل سه بعد خستخى از شفقت، فرسودگى شغلى و

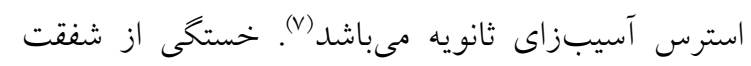

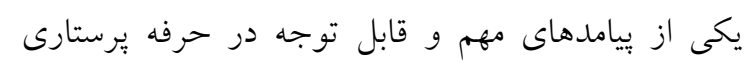

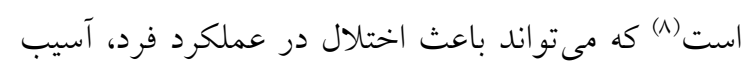
روانى، افت كيفيت و برآيند مراقبت شده و به به تدريج

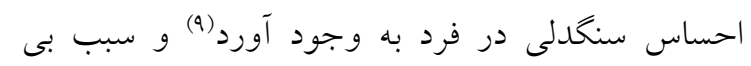

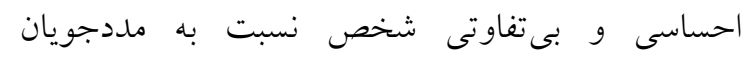

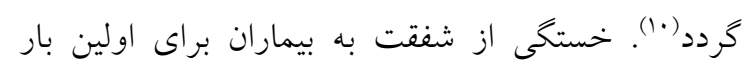

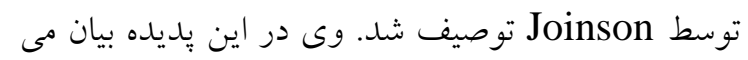

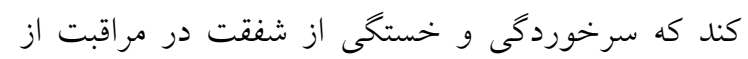

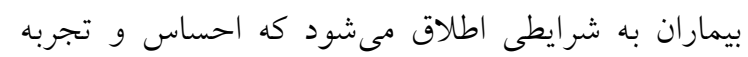
كمك به ديخر ان در افراد مراقبت كننده به واسطه مشاهده

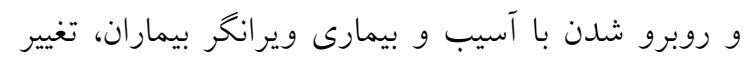

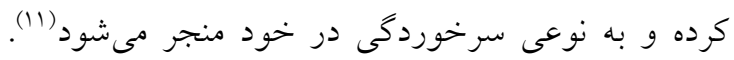


اصلى را ايفاء مى كنند و از سويى وجود محركهاى تنش

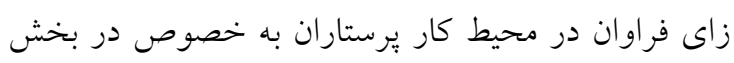

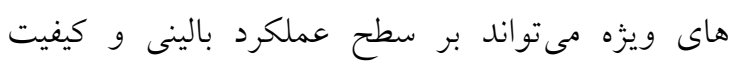

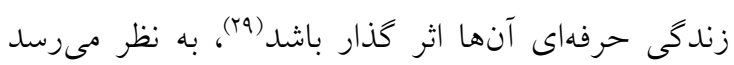

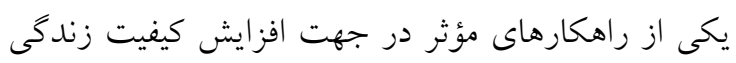

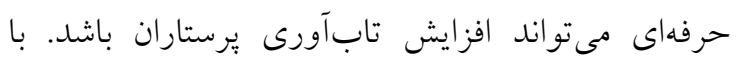

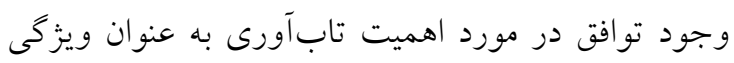

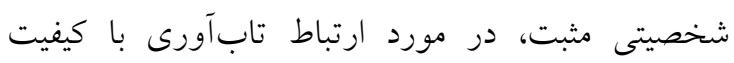

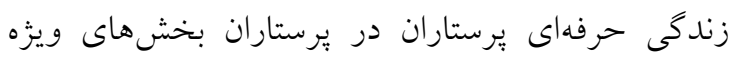

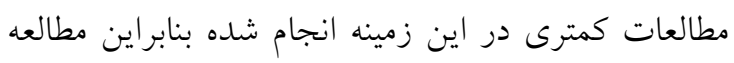

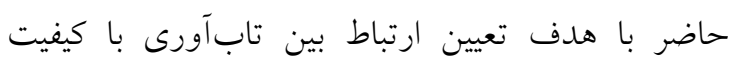

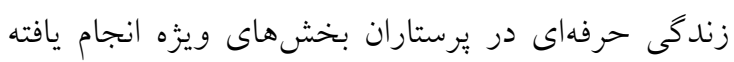

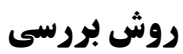

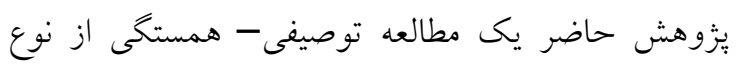

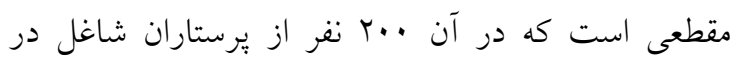
بخش هاى ويزه بيمارستانهاى آموزشى وابسته به دانشعاه

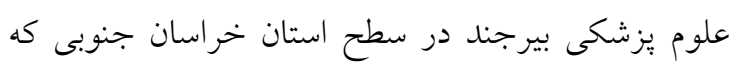

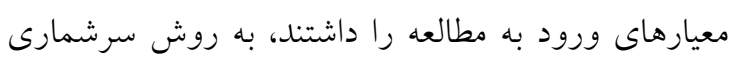
وارد مطالعه شدند. معيارهاى ورود شامل كارشناسان يرستارى بودند كه حداقل يك سال سابقه كار درد

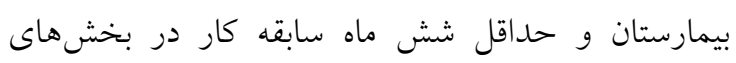
مورد مطالعه را داشتند.

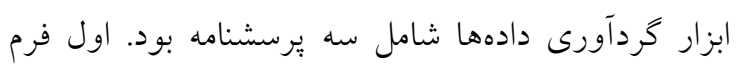
مشخصات فردى و شغلى (جنس، سن، وضعيت تأهل،

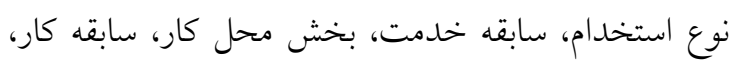

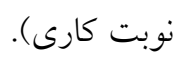

تابآورى با استفاده از ابزار Scale) CD-RISC (Connor-Davidson Resilience Connor-Davidson

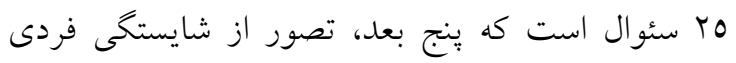

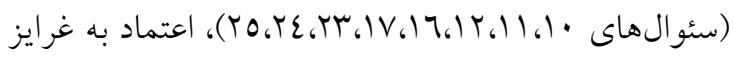
فردى تحمل عاطفه منفى (سئوالهاى 7، V، عا، 10، 11،
״س ممكن است يُرستاران بخشهاى ويزه بيشتر در معرض كاهش كيفيت زندگى حرفهاى قرار بخيرند (19).

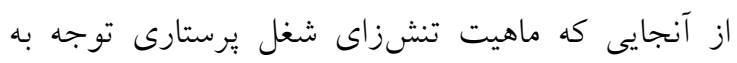
ظرفيتهاى فردى و روانى كه فرد به كمى آنها بتواند

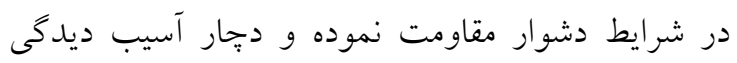

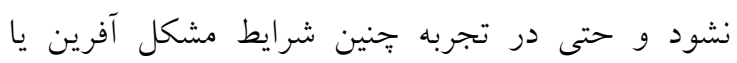

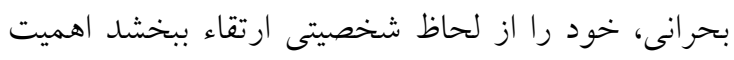

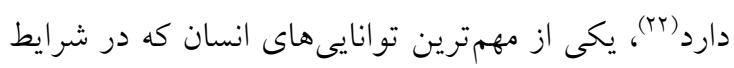

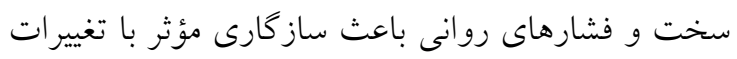

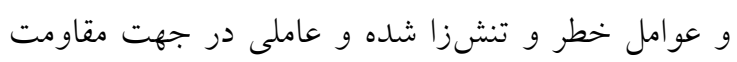
در برابر مشكلات است، تابآورى مى باشد (rr). در تأييد

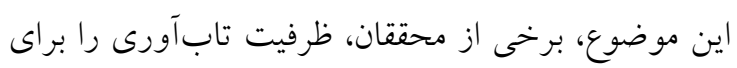

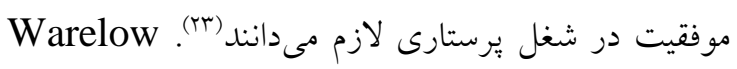

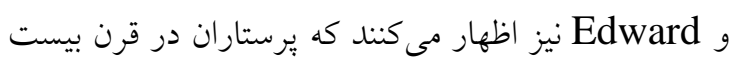

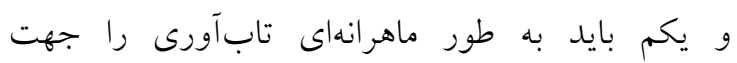
رويارويى با مشكلات حرفهاى، در خود كسترش دهند تا باتئ بر تجارب منفى غلبه كرده و اين تجارب را به تجارب

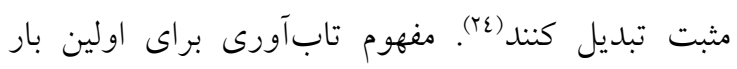
توسط Werner و Smith در روانشناسى رشد مطرح و

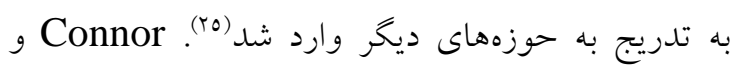

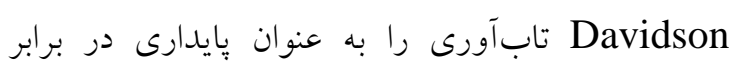

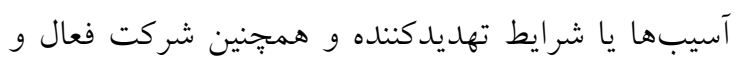
سازنده فرد در محيط مىدانند كه موجب توانمندى فرد

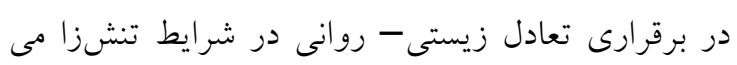

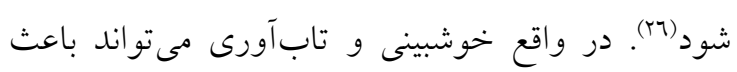
بهبود كيفيت زندگى و خودكارامدى يرستاران شود (TV).

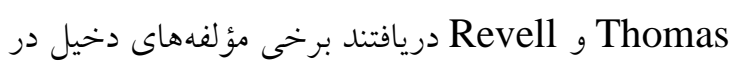

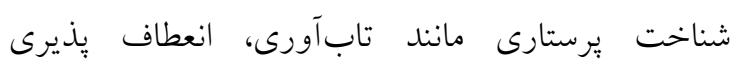

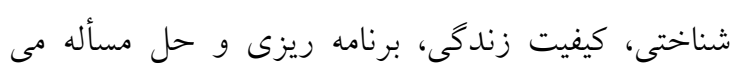

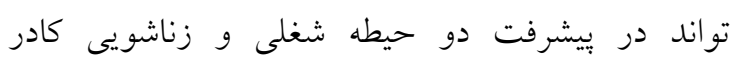

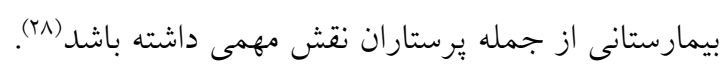

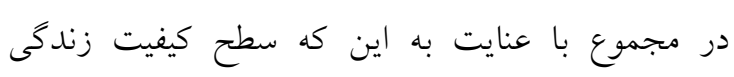

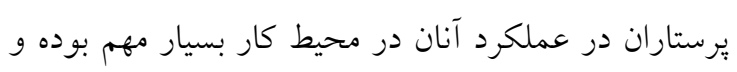

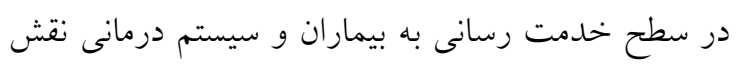


روايى محتواى \&austell Waltz \& ميزان مربوط

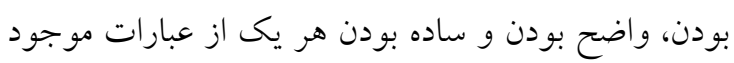
در ابزارها را بر اساس شاخص سه قسمتى تعيين نمايند. هِ از جمع آورى نظرات اساتيد، تغييرات لازم اعمال

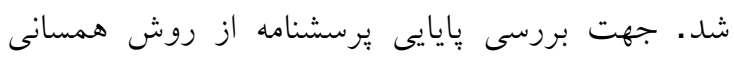

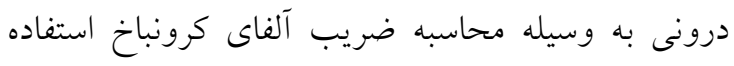
شد. بدين ترتيب كه از 10 نفر از يرستاران شاغل در بخشهاى ويزه كه داراى معيارهاى ورود به مطالعه بودند

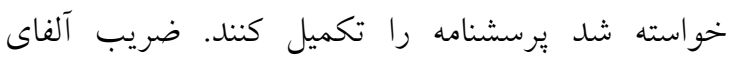

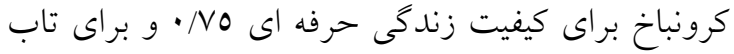

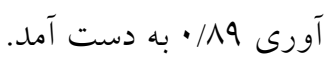

يزوهشگران ابتدا با كسب مجوز از كميته اخلاق دانشخاه علوم يزشكى بيرجند (IR.BUMS.REC.1396.331)

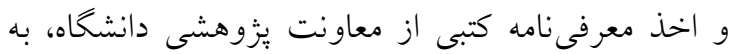

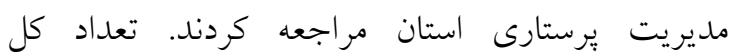
يرستارانى كه در بخشهاى ويزه بيمارستانهاى سطح

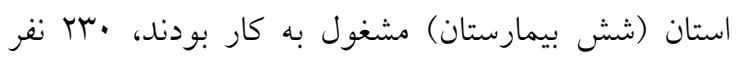

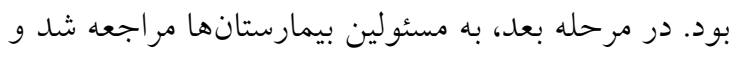

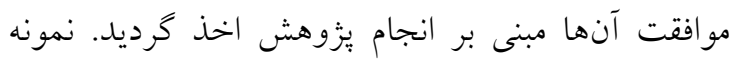

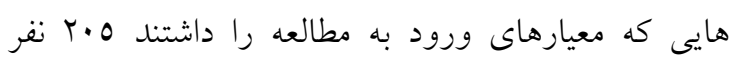
بودند كه بعد از كرفتن رضايتنامه از آنها و توضيح روندكار، وارد مطالعه شدند. توضيحات لازم درباره محرمانه بودن اطلاعات و زمان تحويل يرسشنامهها به

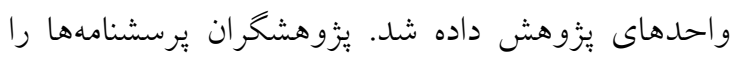
در نوبتهاى كارى مختلف در اختيار يرستاران قرار داده

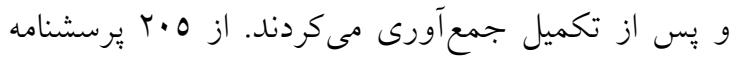

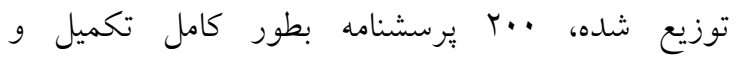
جمع آورى گرديد. جمع آورى دادهها دو ماه به طول بهول انجاميد. در اين يزوهش اصول اخلاقى از جمله اخذ

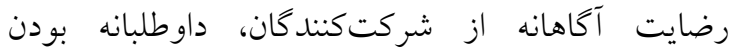
مشاركت و داشتن اختيار خروج از يُزوهش، اخذ مجوزهاى لازم براى ورود به محيط يُزوهش و امانتدارى در استفاده از منابع رعايت شده است.
19، • (Y)، يذيرش مثبت تغيير و روابط ايمن (سئوالهاى

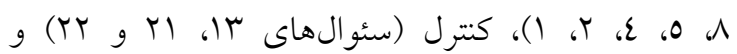

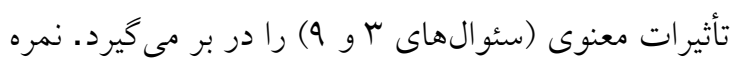

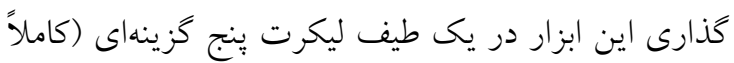

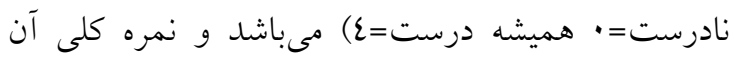

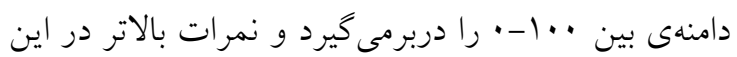

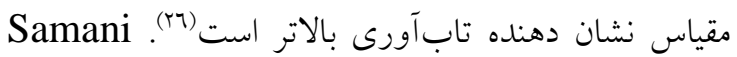

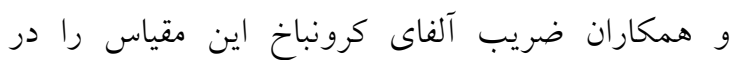
دانشجويان AV/ • به دست آوردهاند (•r).

Professional ) برسشنامه كيفيت زندكى حرفهاى

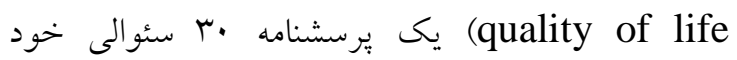

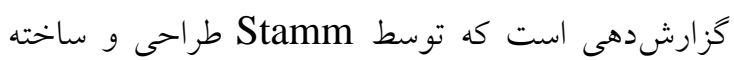
شده است (V). شامل سه بعد خستخكى از شفقت (سئوال

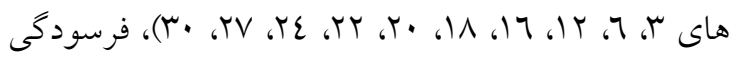

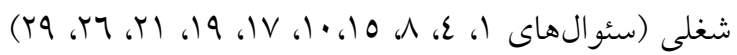

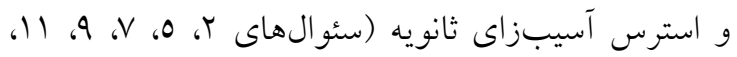

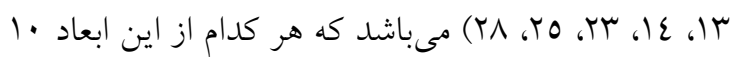

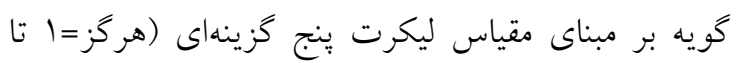

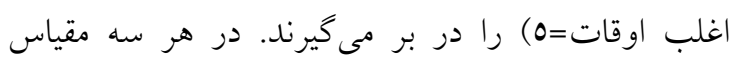

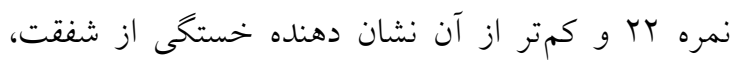
فرسودكى شغلى و استرس آسيبزاى ثانويه كمتر، نمره

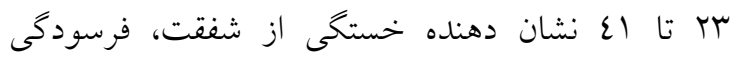

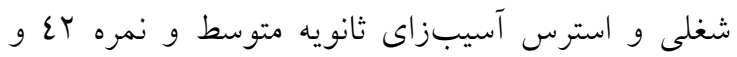
بالاتر نشان دهنده خستخى از شفقت، فرسودكى شغلى و و

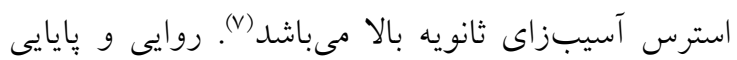

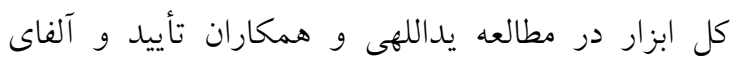

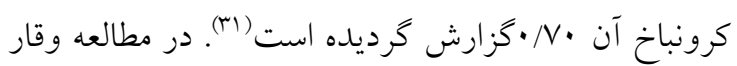

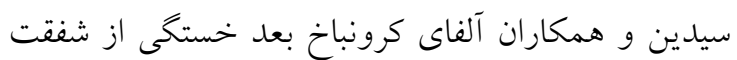

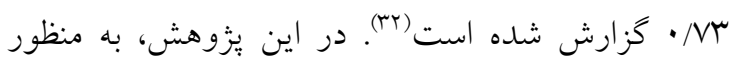
تعيين روايى زيرس نامههاى مذكور از روش روايى محتوا استفاده شد؛ بدين ترتيب يزوهشكران يرسشنامهها را در اختيار •ا نفر از اعضاى هيئت علمى دانشكده يرستارى و مامايى دانشخاه علوم يزشكى بيرجند قرار

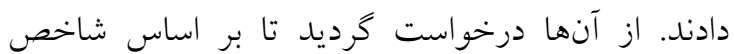


در اين مطالعه از 0.T برسشنامه توزيع شده در مجموع

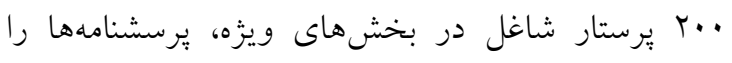
تكميل كرده و تحويل دادند. Vo/0 درصد از شركت كندكان زن، V7 درصد متأهل، 07 درصد بين •r-r سال، M/O درصد شاغل در ICU ، ، I0 درصد سابقه كار كمتر از ״ينج سال، 9/0 درصد شيفت درگردش و رب

$$
\text { درصد استخدام بيمانى بودند. }
$$

دادهها با استفاده از آمار توصيفى (فراوانى و درصد، ميانخين و انحراف معيار) و آمار تحليلى (كروسكالواليس، تى تست، آناليز واريانس و ضريب همبستخى بيرسون) در نرم افزار SPSS نسخه 7 (1، در سطح معنى دارى P> P Pورد تجزيه و تحليل قرار كرفت.

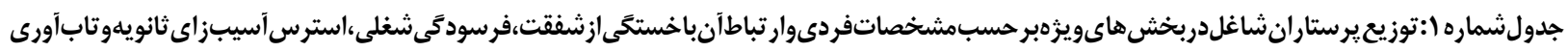

\begin{tabular}{|c|c|c|c|c|c|}
\hline تاب آورى & استرس آسيبزاى ثانويه & فرسودگى شغلى & خستكى از شفقت & (درصد) تعداد & متغير \\
\hline آزمون كروسكالو اليس & & آزمون تىتست & & & جنس \\
\hline \multirow[t]{2}{*}{$\mathrm{P}=\cdot / v_{0}$} & $\mathrm{P}=\cdot / 10$ & $\mathrm{P}=\cdot / 10$ & $\mathrm{P}=\cdot / V T$ & $\varepsilon q(Y \varepsilon / 0)$ & مرد \\
\hline & & & & $101(\mathrm{~V} 0 / 0)$ & زن \\
\hline ازمون كروسكالو اليس & & ازمون آنوا & & & سن \\
\hline \multirow[t]{3}{*}{$\mathrm{P}=\bullet / \cdots \wedge$} & $\mathrm{P}=\cdot / 00$ & $\mathrm{P}=\cdot / 00$ & $\mathrm{P}=\cdot / \mu$ & $11 Y(07)$ & $r \cdot-r \cdot$ \\
\hline & & & & $O\{(Y V)$ & $\varepsilon \cdot-r$. \\
\hline & & & & $r \varepsilon(I V)$ & $\varepsilon \cdot>$ \\
\hline آزمون منويتنى & & آزمون تى تست & & & وضعيت تأهل \\
\hline \multirow[t]{2}{*}{$\mathrm{P}=\cdot / 9 r$} & $\mathrm{P}=\cdot / \varepsilon 0$ & $\mathrm{P}=\cdot / \mathrm{T}$ & $\mathrm{P}=\cdot / \mathrm{V}$ & $\varepsilon \wedge(Y \varepsilon)$ & مجرد \\
\hline & & & & $\operatorname{lor}(\mathrm{VT})$ & متأهل \\
\hline آزمون كروسكالو اليس & & ازمون آنوا & & & بخش \\
\hline \multirow[t]{4}{*}{$\mathrm{P}=\cdot / \Lambda \Lambda$} & $\mathrm{P}=\cdot / V T$ & $\mathrm{P}=\cdot N Y$ & $\mathrm{P}=\bullet / V Y$ & $71(r \cdot / 0)$ & $\mathrm{CCU}$ \\
\hline & & & & $V O(Y V / O)$ & ICU \\
\hline & & & & $r q(19 / 0)$ & $\mathrm{NICU}$ \\
\hline & & & & rO $(I T / 0)$ & دياليز \\
\hline آزمون كروسكالو اليس & & آزمون تى تست & & & نوبت حرفه اى \\
\hline \multirow[t]{2}{*}{$\mathrm{P}=\cdot / \cdot r$} & $\mathrm{P}=\cdot / 00$ & $\mathrm{P}=\cdot / 77$ & $\mathrm{P}=\cdot / \cdot \varepsilon$ & $\mu(7 / 0)$ & ثابت \\
\hline & & & & $1 \wedge 7(9 \% / 0)$ & شيفت در گردش \\
\hline آزمون كروسكالو اليس & & ازمون آنوا & & & سابقه كار (سال) \\
\hline \multirow[t]{5}{*}{$\mathrm{P}=\cdot / 01$} & $\mathrm{P}=\cdot / r V$ & $\mathrm{P}=\cdot / 90$ & $\mathrm{P}=\cdot / \cdot 0$ & $1 \cdots(0 \cdot)$ & > از 0 سال \\
\hline & & & & $01(Y 0 / 0)$ & 0--· سال \\
\hline & & & & $1 \mu(7 / 0)$ & $10-1$ \\
\hline & & & & $r \varepsilon(I Y)$ & 10 r.-10 سال \\
\hline & & & & $M(7)$ & $r \cdot j \mid>$ \\
\hline آزمون كروسكالو اليس & & ازمون آنوا & & & نوع استخدامى \\
\hline \multirow[t]{5}{*}{$\mathrm{P}=\cdot / \cdot r$} & $\mathrm{P}=\cdot \pi r$ & $\mathrm{P}=\cdot / \mathrm{V}$ & $\mathrm{P}=\cdot / \cdot 7$ & $07(Y \Lambda)$ & رسمى \\
\hline & & & & $V V(\Gamma \wedge / O)$ & ييمانى \\
\hline & & & & $r V(\mid r / 0)$ & قراردادى \\
\hline & & & & $r q(1 \varepsilon / 0)$ & شركتى \\
\hline & & & & $11(0 / 0)$ & طرحى \\
\hline
\end{tabular}


سن، نوبت حرفهاى و وضعيت استخدام از نظر آمارى

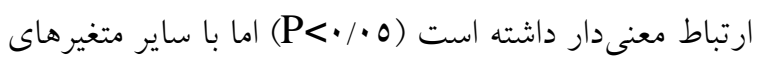
فردى و شغلى ارتباط آمارى معنىدار مشاهده نشد. بدين

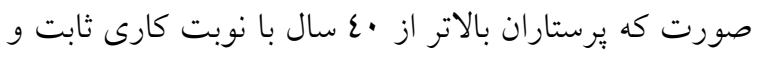

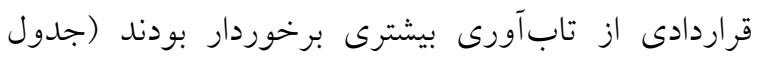

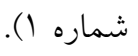

نتايج همجينين نشان داد كه بيشتر يرستاران ميزان خستخى از

شفقت، فرسودكى شغلى و استرس آسيبزاى ثانويه را متوسط گزارش كردند (جدول شماره Y).
براى بررسى ارتباط نمرات تابآورى و ابعاد كيفيت زندكى

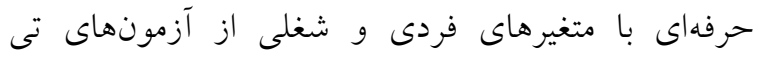

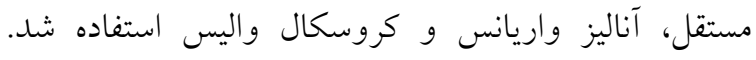

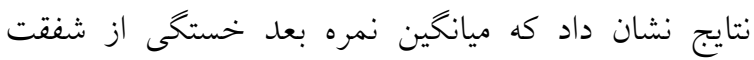
كيفيت زندكى حرفهاى با متغيرهاى نوبت حرفهاى و سابقه

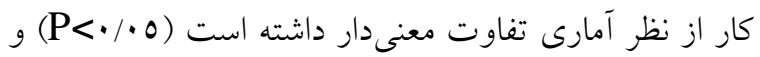

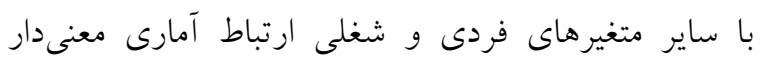

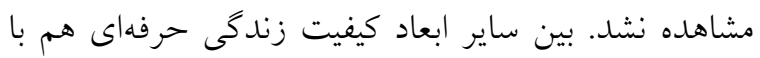

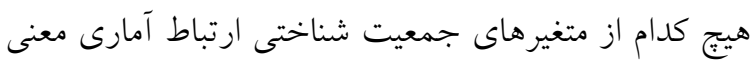
دارى وجود نداشت. همجينين نمره تابآورى با متغيرهاى

جدول شماره ؟: توصيف نمرات ابعاد كيفيت زندَى حرفهاى در برستاران شاغل در بخشهاى ويزه

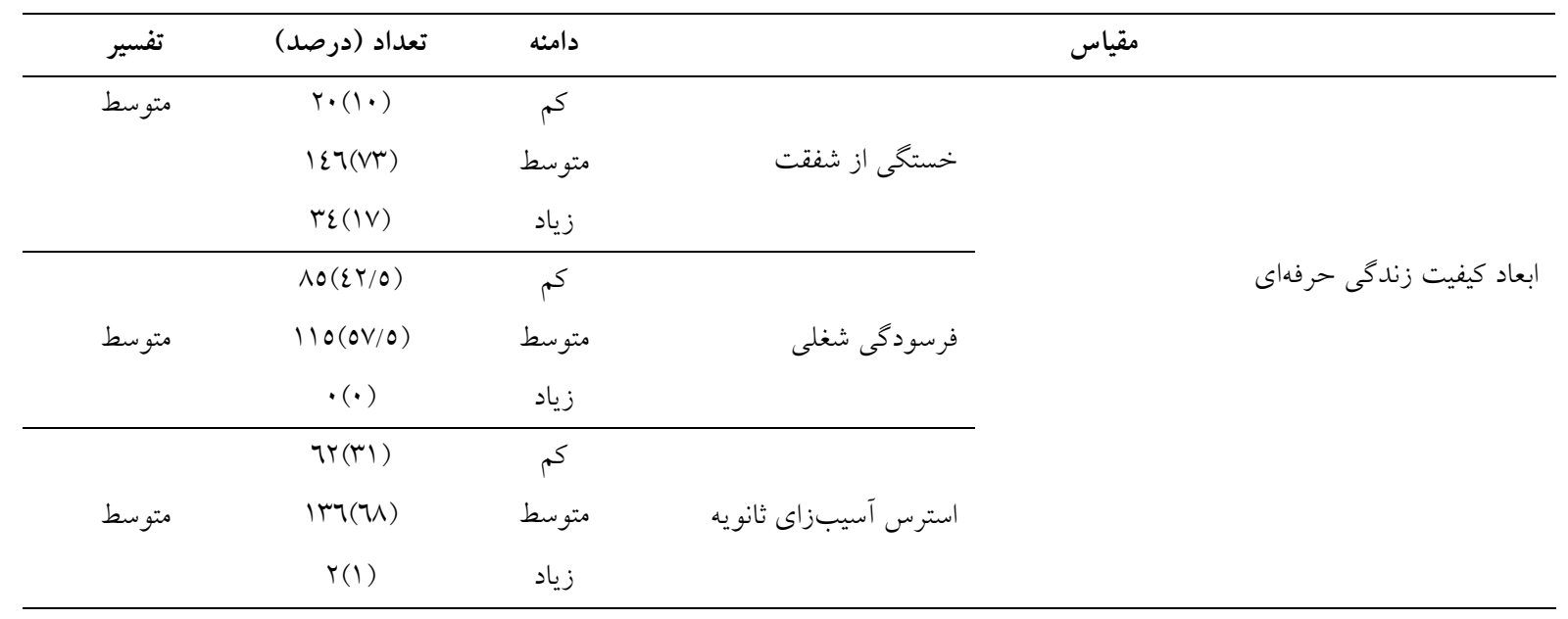

اى بيشترين ميانخين نمره مربوط به بعد خستخى از شفقت نتايج همجنين نشان داد كه ميانكين نمره كل تاب آورى

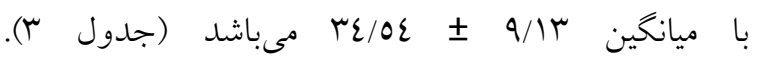

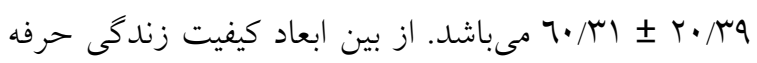
جدول شماره سا: توصيف ميانكين نمرات تابآورى و ابعاد آن و كيفيت زندكى حرفهاى و ابعاد آن در يرستاران شاغل در بخشهاى ويزه

\begin{tabular}{|c|c|c|}
\hline انحراف معيار 土 ميانكين & متغيرها & \\
\hline $7 \cdot / r 1 \pm r \cdot / r q$ & 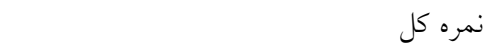 & \\
\hline $\mid N / O V \pm \varepsilon / q r$ & بعدتصور از شايستخى فردى & \\
\hline $10 / 17 \pm \varepsilon / 09$ & بعد اعتماد به غرايز فردى-تحمل عاطفه منفى & 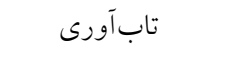 \\
\hline ITNY $\pm r / V T$ & بعد هذيرش مثبت تغيير و روابط ايمن & \\
\hline$N / T \pm 1 \varepsilon / \Lambda$ & بعد كنترل & \\
\hline$\Delta / N \pi \pm 1 / \pi$ & بعد تأثيرات معنوى & \\
\hline $10 / .9 \pm 1 / 7 \mathrm{~V}$ & 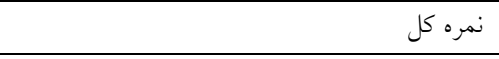 & \\
\hline$r \varepsilon / 0 \varepsilon \pm 9 / 1 r$ & بعد خستخى از شفتت & \\
\hline$r \varepsilon / 7 \pm \Delta / V$. & بعد فرسودكى شغلى & كيفيت زندگى حرفهاى \\
\hline$r T / 2 q \pm V / \wedge T$ & بعد استرس آسيبزاى ثانويه & \\
\hline
\end{tabular}


ابعاد تابآورى ارتباط معكوس و معنىدارى وجود دارد

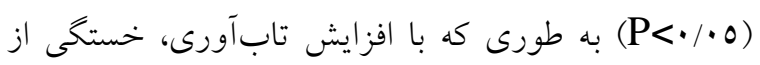

شفقت افراد كاهش مى يابد (جدول شماره ع).
جهت بررسى ارتباط تابآورى و ابعاد آن با كيفيت زندكى حرفهاى و ابعاد آن از ضريب همبستكى بيرسون استفاده تباد

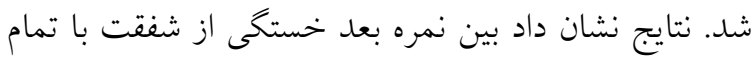

جدول شماره ع: ارتباط بين نمرات ابعاد تابآورى با ابعاد نمرات كيفيت زندكى حرفهاى در يرستار ان شاغل در بخشهاى ويزه

\begin{tabular}{|c|c|c|c|c|c|c|}
\hline تأثيرات & كنترل & تغعد پِيرش مثبت و روابط ايمن & 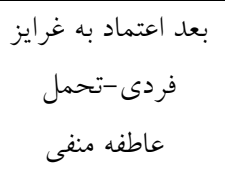 & شعد تصور از & نمره كل & \\
\hline $\mathrm{r}=\cdot / 10 \mathrm{~V}$ & $\mathrm{r}=\cdot / \cdot \varepsilon$. & $r=. / .9 \varepsilon$ & $r=\cdot / 1 \cdot \varepsilon$ & $\mathrm{r}=\cdot / T r \wedge$ & $r=. / 1 r q$ & نمره كل \\
\hline $\mathrm{P}=\bullet / \cdot r\urcorner$ & $P=\cdot /$ orq & $\mathrm{P}=\cdot / \wedge \wedge \vee$ & $\mathrm{P}=\cdot / 1 \varepsilon r$ & $\mathrm{P}=\bullet / \cdot \cdot 1$ & $\mathrm{P}=\cdot / \cdot \varepsilon$ & \\
\hline $\mathrm{r}=-\cdot / \mathrm{r} 77$ & $r=-\cdot / \cdot \wedge 7$ & r=-• r r & $\mathrm{r}=-\cdot / r V T$ & $\mathrm{r}=-\cdot \cdot \varepsilon \cdot v$ & $\mathrm{r}=-\cdot / r 77$ & بعد خستخى از شفقت \\
\hline $\mathrm{P}=\cdot / \cdots 1$ & $\mathrm{P}=\cdot / r \uparrow \wedge$ & $\mathrm{P}=\cdot / \cdots 1$ & $\mathrm{P}=\cdot / \cdot \cdot 1$ & $\mathrm{P}=\cdot / \cdot \cdot 1$ & $\mathrm{P}=\cdot / \cdots 1$ & \\
\hline$r=-\cdot / \cdot v \varepsilon$ & $\mathrm{r}=-\cdot / \cdot \varepsilon \cdot$ & $\mathrm{r}=-\cdot 1 \cdot 17$ & $\mathrm{r}=-\cdot / \cdot \varepsilon\rceil$ & $r=-\cdot / \cdot v \cdot$ & $\mathrm{r}=-\cdot / \cdot 1 \mathrm{r}$ & بعد فر \\
\hline $\mathrm{P}=\cdot / \pi 99$ & $\mathrm{P}=\cdot / 0 \mathrm{~V} r$ & $\mathrm{P}=\cdot / \Lambda r r$ & $\mathrm{P}=\cdot / 0 r$. & $\mathrm{P}=\cdot / \pi r \varepsilon$ & $\mathrm{P}=\cdot / \wedge \pi T$ & \\
\hline $\mathrm{r}=-\cdot / \cdot \mathrm{rV}$ & $r=-\cdot / \cdot r r$ & $\mathrm{r}=-\cdot / \cdot \wedge r$ & $\mathrm{r}=-\cdot \cdot \cdot 71$ & $r=-\cdot / \cdot r r$ & $\mathrm{r}=-\cdot / \cdot r \varepsilon$ & بعد استرس آسيبزاى ثانويه \\
\hline $\mathrm{P}=\cdot / \mathrm{V} \cdot 7$ & $\mathrm{P}=\cdot / \vee \varepsilon \wedge$ & $\mathrm{P}=\cdot / r \varepsilon 0$ & $\mathrm{P}=\cdot / r q \mu$ & $\mathrm{P}=\cdot / 71 \varepsilon$ & $\mathrm{P}=\cdot / \mu^{\mu} \wedge$ & \\
\hline
\end{tabular}

در اين مطالعه از بين متغيرهاى جمعيت شناختى و شغلى فقط نوبت كارى و سابقه كارى ارتباط معنىدارى با بعد خستخى از شفقت كيفيت زندگى حرفهاى برستاران داشتند. يافتههاى Abendroth و Flannery ارتباط بين تعداد سالهاى خدمت را با خستخى از شفقت به بيماران مورد تأييد قرار داده حاكى از آن است كه هر جهه سن افراد بالاتر مى رود، به دليل تغييرات فردى و شخصيتى كه در فرد رخ مىدهد، توان رويارويى آنان با حوادث استرسزاى مربوط به بيماران و تطابق مؤثر با آنها كاهش مىيابد (َس). در مطالعهاى كه Yoder با هدف خستخى از شفقت برستاران در هند انجام داده بود نيز اين ارتباط مستقيم را معنىدار كزارش كرده و بيان مىكند كه افزايش تعداد سالهاى خدمت در كنار افزايش سن مىتواند باعث نوعى خستخى از شفقت در برستاران شود Mendes نيز بيان مى كند كه افراد در انتهاى سالهاى خدمت خود با مجموعهاى از خاطرات شغلى ناخوشايند روبرو هستند كه مىتوانند آنها

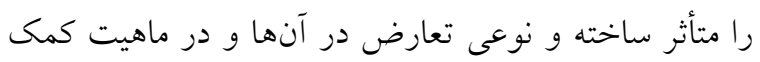

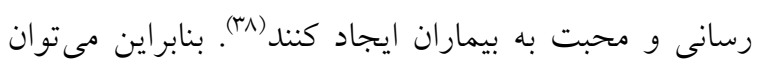
كفت با افزايش سابقه كارى و سن، افراد به بيمارىهاى
بحث و نتيجه كيرى

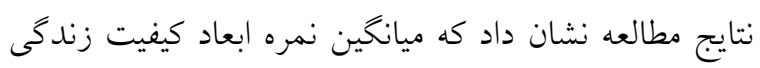

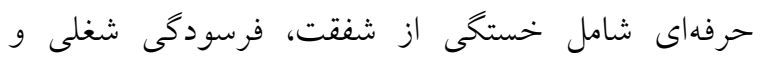

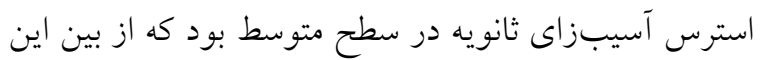

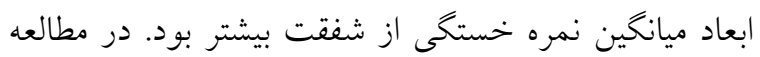

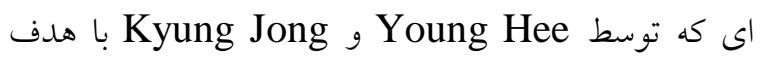
تعيين خستخى از شفقت، فرسودگى شغلى و استرس آسيب

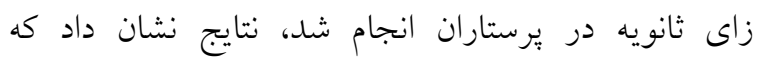
يرستاران سطح متوسطى از اين ابعاد را تجربه كردهاند (Tr).

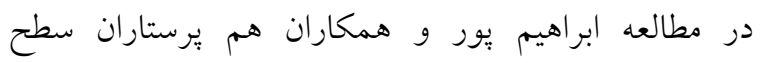

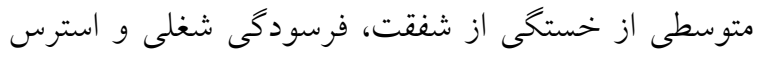

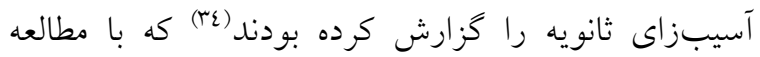

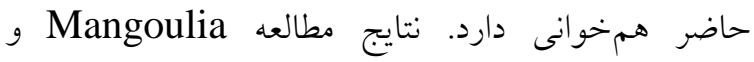
همكاران نشان داد كه $07 / 1$ درصد يرستاران بخشهاى ويزّه در معرض خطر بالاى فرسودىى شغلى بودند و 71/0

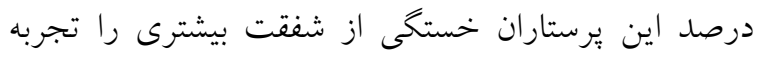

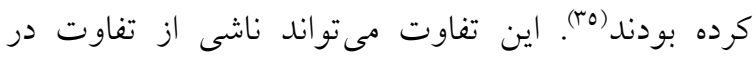

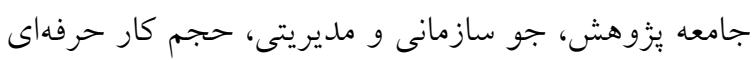
و تفاوت در دريافتى برستاران در جوامع مختلف باشد. 
اين نتايج ضد و نقيض هم نياز به مطالعات بيشتر را خاطر نشان مىسازد. در ارتباط بين نمرات ابعاد تابآورى با ابعاد نمرات كيفيت

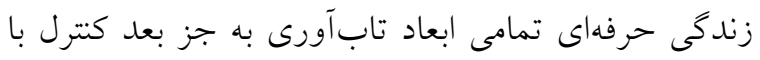

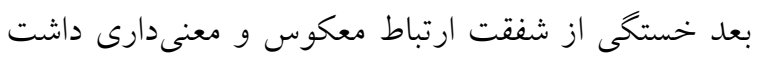
و با بقيه ابعاد ارتباط معنىدارى وجود نداشت. نتايج اين

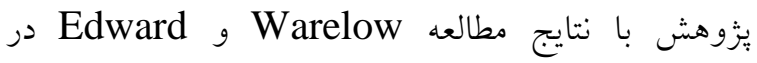
استراليا هم سو است كه نشان داد يرستارانى كه در رويارويى با مشكلات حرفهاى جهت حفظ سلامت خود از رفتارها و ظرفيتهاى تابآورانه بهره مى گيرند، كمتر دجّار خستخى عاطفى و فرسودگى شغلى مى وشوند (17). نتايج مطالعات Menezes و همكاران، Edward و نشان داد كه يرستارانى كه از تابآورى Hercelinsky بالاترى برخوردارند و از فنون تقويت كنده تابآورى

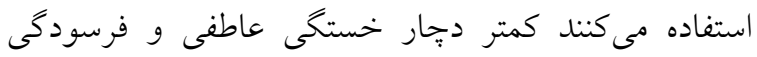

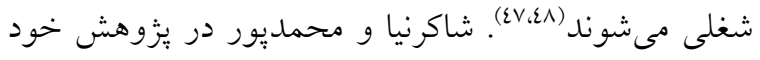

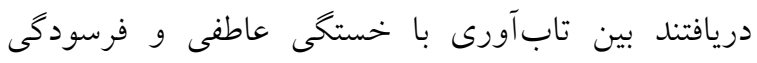

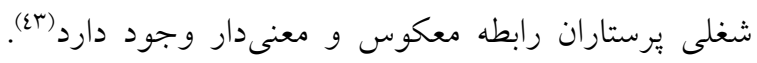

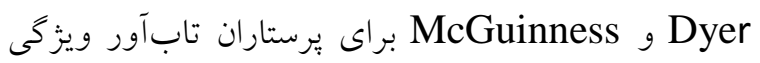
هاى مهمى شامل انعطاف يذّيرى، خستخى نايذيرى، خود

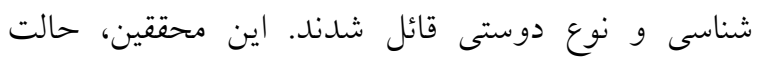

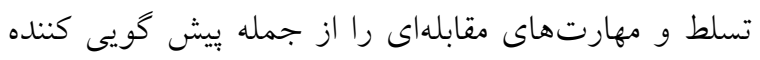

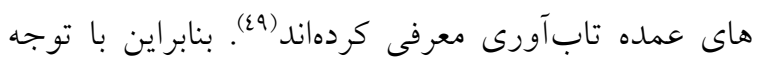

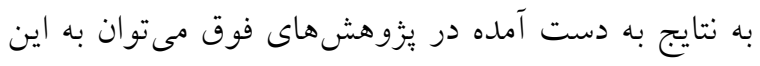

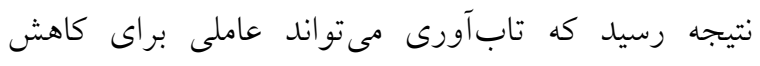

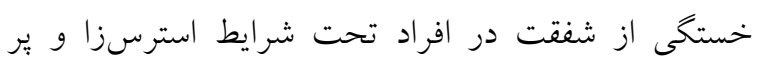
تنش همجيون شغل يرستارى گردد. حال با توجه به نتايج حاصل از اين مطالعه كه نشان دهنس ردنده سطح متوسط ابعاد كيفيت زندگى حرفهاى است، جهت

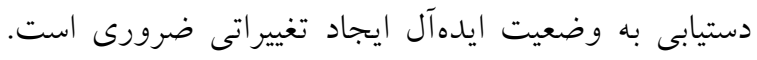

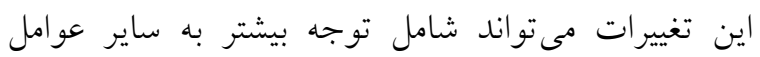
مؤثر بر كيفيت زندگى حرفهاى توسط محققان، مديران و

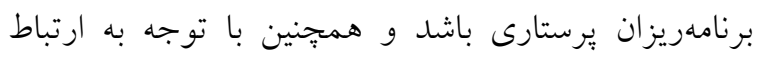

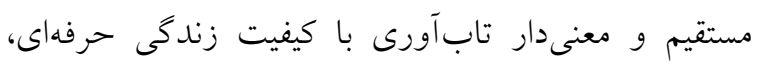

مزمن و مختلف مبتلا مىشوند و ابعاد مختلف كيفيت زندكى حرفهاى افراد افت بيدا مى كند.

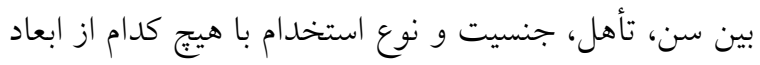

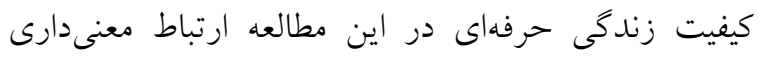

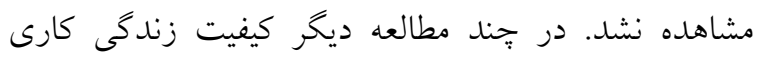
برستاران با افزايش ساعات اضافه كاهش داشته است (•، دهم). در مطالعهاى كه با هدف تعيين عوامل مؤثر بر كيفيت زندكى كارى برستاران توسط مرادى و همكاران انجام شد،

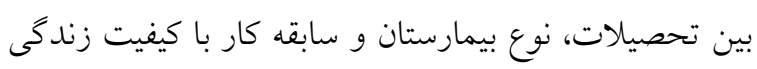

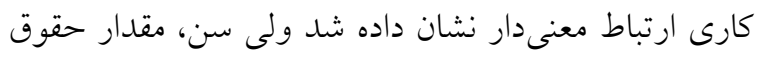

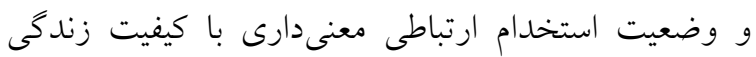

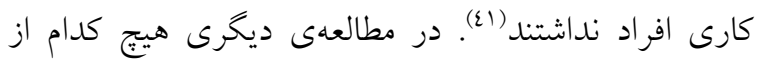

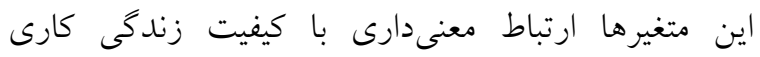

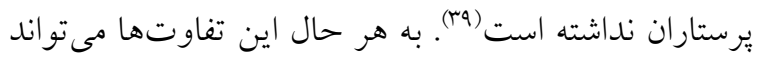

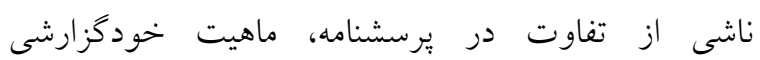

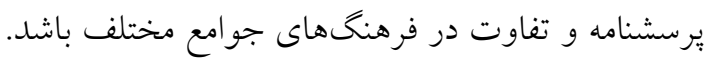

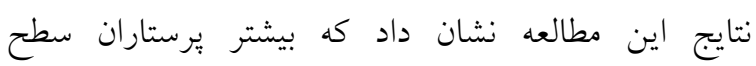

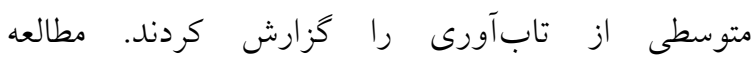
Shakerinia را در برستاران به خصوص در بخشهاى ويزه بالا نشان

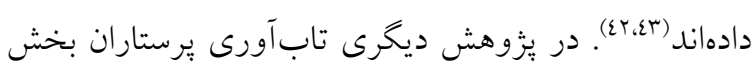

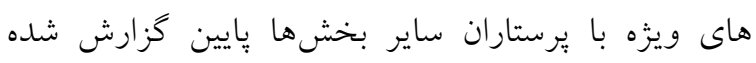

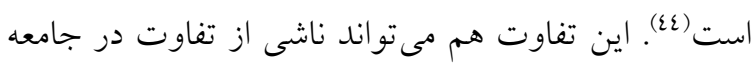

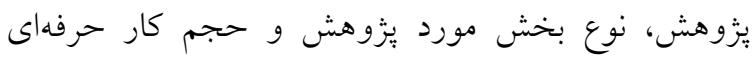
يرستاران در بخشهاى مختلف باشد و همرينين اين نتايج ضد و نقيض نياز به مطالعات بيشتر را خاطر نشان مى سازد.

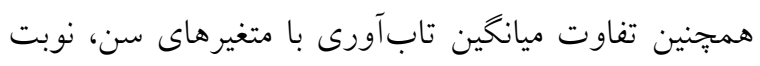

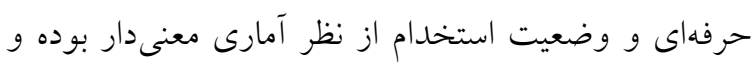
با ساير متغيرهاى فردى و شغلى تفاوت آمارى معنى ودار

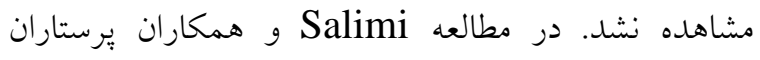
شيفت عصر بخش ICU تابآورى بالاترى را خزارش كرده بودند (זT). در مطالعه Lee و همكاران در آمريكا نيز برخى از مشخصات جمعت شناختى با تابآورى يرستاران

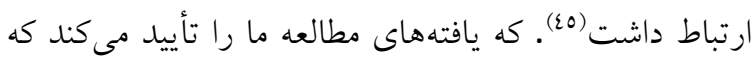




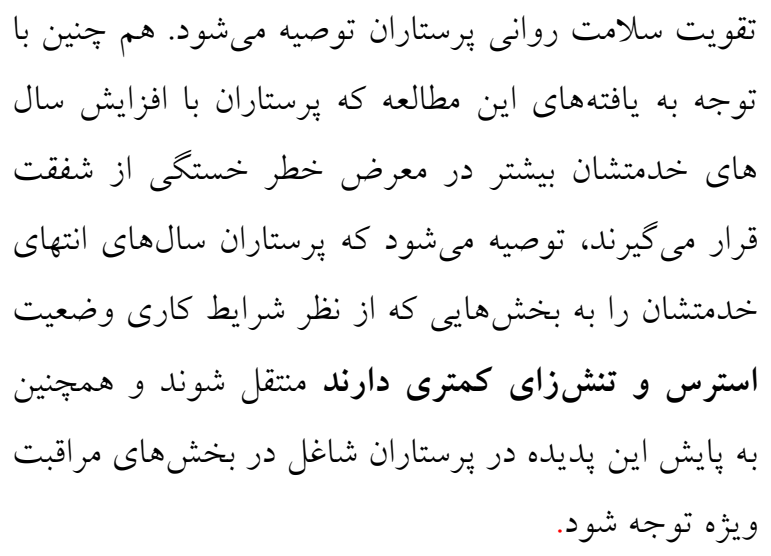

\section{تقدير و تشكر}

از تمامى يرستاران مراكز آموزشى- درمانى وابسته به

دانشگاه علوم يزشكى بيرجند كه در اين مطالعه شركت

نمودند تشكر مىشود. لازم به ذكر است كه اين مقاله

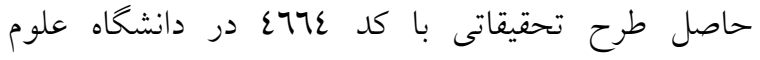

يزشكى بيرجند مىباشد و اعتبار آن از اين محل تأمين شده

$$
\begin{aligned}
& \text { ارايه راهكارهايى از جمله ايجاد شبكه حمايتى - اجتماعى، }
\end{aligned}
$$

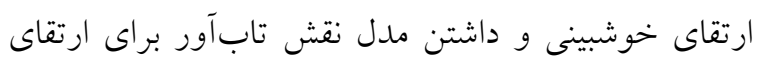

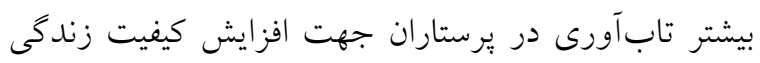

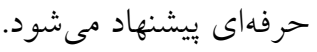

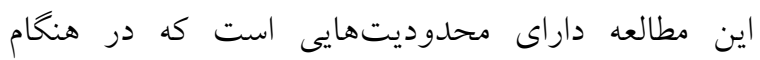

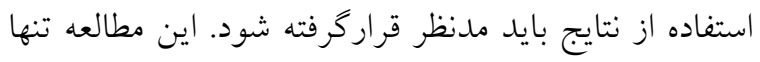

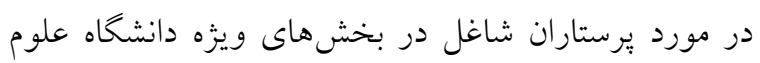

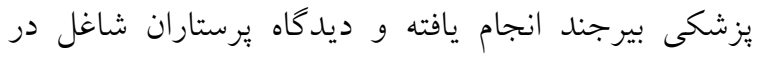

$$
\begin{aligned}
& \text { ساير بخشها و همجنين مديران برستارى در نظر گرفته } \\
& \text { نشده است. بنابراين بيشنهاد مى شود كه مطالعاتى در محيط } \\
& \text { هاى ديخر و با در نظركرفتن نظرات مديران يرستارى و } \\
& \text { يرستاران شاغل در ساير بخشها صورت كيرد. همجنين } \\
& \text { شرايط روانى شركت كنندكان در زمان تكميل يرسشنامهها }
\end{aligned}
$$

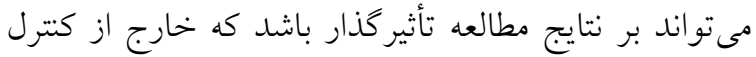

$$
\begin{aligned}
& \text { يزوهشخر بود. } \\
& \text { بنابراين با توجه به نتايج اين مطالعه كه ارتباط معنى دار و }
\end{aligned}
$$

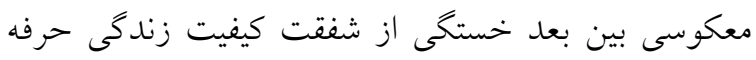

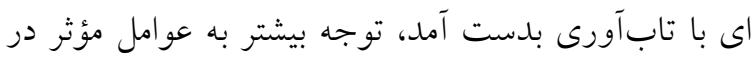

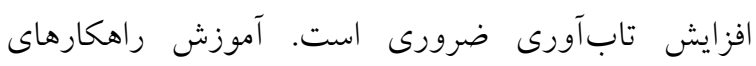

$$
\begin{aligned}
& \text { تقويت تابآورى در برنامه آموزشى يرستاران به منظو آنظور }
\end{aligned}
$$

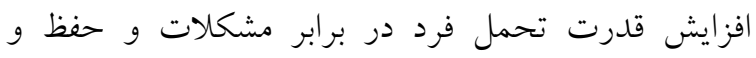

\section{References}

1. Farhadi P, Sharifian R, Feili A, Shokrpour N. The effects of supervisors' supportive role, job stress, and work-family conflicts on the nurses' attitudes. The health care manager. 2013;32(2):107-22.

2. Khodayarian M, Vanaki Z, Navipour H, Vaezi A. The Effects of Designed Clinical CompetencyBased Advancement Program on the Ccu Nurses'quality of Work Life. 2008;15(75):15-26. [Perssian]

3. Horrigan JM, Lightfoot NE, Larivière MA, Jacklin K. Evaluating and improving nurses' health and quality of work life: A cross-sectional study of Korean blue collar workers employed by small businesses. Workplace Health \& Safety. 2013;61(4):173-81.

4. Najjar N, Davis LW, Beck-Coon K, Carney Doebbeling C. Compassion fatigue: A review of the research to date and relevance to cancer-care providers. Journal of Health Psychology. 2009;14(2):267-77.

5. Circenis K, Millere I, Deklava L. Measuring the professional quality of life among Latvian nurses. Procedia Soc Behav Sci. 2013;84:1625-9.

6. Kim K, Han Y, Kim J-s. Korean nurses' ethical dilemmas, professional values and professional quality of life. Nursing ethics. 2015;22(4):467-78.

7. Stamm B. The concise ProQOL manual . Pocatello, ID. Retrieved from ProQOL org. 2010.

8. Hunsaker S, Chen HC, Maughan D, Heaston S. Factors that influence the development of compassion fatigue, burnout, and compassion satisfaction in emergency department nurses. $J$ Nurs Scholarsh. 2015;47(2):186-94. 
9. Bush NJ, editor Compassion fatigue: Are you at risk? Oncol Nurs Forum. 2009;36(1):24-8.

10. Kim S. Compassion fatigue in liver and kidney transplant nurse coordinators: A descriptive research study. Progress in Transplantation. 2013; 23(4):329-35.

11. J Joinson C. Coping with compassion fatigue. Nursing. 1992; 22(4):116-8.

12. Beck CT. Secondary traumatic stress in nurses: A systematic review. Arch Psychiatr Nurs. 2011; 25(1):1-10.

13. Delpasand M, Nasiripoor AA, Raiisi P, Shahabi M. The relationship between emotional intelligence and occupational burnout among nurses in critical care units. Iranian journal of critical care nursing. 2011; 4(2):79-86. [Persian]

14. Moumeni H, Salehi A, Seraji A. The comparison of burnout in nurses working in clinical and educational sections of Arak University of Medical Sciences in 2008. Arak Med Univ J. 2010; 12(4):113-23. [Persian]

15. Mosavianasl Z, Babaeipouya A, Karimi A. The Relationship between Shift Work and Occupational Burnout among Nurses in a Teaching Hospital in Ahva. Promot J. 2017; 1(2):118-28. [Persian]

16. Mazloumi A, Kazemi Z, Mehrdad R, Helmi Kohneh Shahri M, Pour Hossein M. Validity and reliability of WRQoL-2 questionnaire for assessment of nurses' quality of work life. Health and Safety at Work. 2017; 7(2):143-52. [Persian]

17. Hesam M, Asayesh H, Roohi G, Shariati A, Nasiry H. Assessing the relationship between nurses' quality of work life and their intention to leave the nursing profession. Quarterly Journal of Nursing Management. 2012; 1(3):28-36. [Persian]

18. Valizadeh S, Haririan H. Nurses Work Motivation: A Big Challenge for Health System; a Review article. Preventive Care in Nursing \& Midwifery Journal. 2016; 5(2):56-64. [Persian]

19. Shafipour V, Momeni B, Yazdani Charati J, Esmaeili R. Quality of Working Life and its Related Factors in Critical Care Unit Nurses. Journal of Mazandaran University of Medical Sciences. 2016; 26(142):117-26. [Persian]

20. Rushton $\mathrm{CH}$, Batcheller J, Schroeder K, Donohue P. Burnout and resilience among nurses practicing in high-intensity settings. Am J Crit Care. 2015; 24(5):412-20.

21. Komeili-Sani M, Etemadi A, Boustani H, Bahreini M, Hakimi A. The relationship between nurses' clinical competency and job stress in Ahvaz university hospital, 2013. Journal of clinical nursing and midwifery. 2015; 4. [Persian]

22. McAllister M, McKinnon J. The importance of teaching and learning resilience in the health disciplines: a critical review of the literature. Nurse Educ Today. 2009; 29(4):371-9.

23. Ahern NR, Norris AE. Examining factors that increase and decrease stress in adolescent community college students. J Pediatr Nurs. 2011; 26(6):530-40.

24. Bagherinia H, Yamini M, Ildarabadi E, Bagherinia F. Relationship between personality traits and mental health with resilience mediation in nurses. Journal of Sabzevar University of Medical Sciences. 2016;22(6):1063-70. [Persian]

25. Werner EE, Smith RS. Overcoming the odds: High risk children from birth to adulthood: Cornell University Press; 1992.

26. Connor KM, Davidson JR. Development of a new resilience scale: The Connor-Davidson resilience scale (CD-RISC). Depression and anxiety. 2003; 18(2):76-82.

27. Napa M. optimism resilience and leadership-3 qualities to help move you toward greatness.2011: http://ezinearticles.com

28. Thomas LJ, Revell SH. Resilience in nursing students: An integrative review. Nurse Educ Today. 2016; 36:457-62.

29. McGrath A, Reid N, Boore J. Occupational stress in nursing. Inter J Nurs Stud. 2003; 40(5):555-65.

30. Samani S, Jokar B, Sahragard N. Effects of resilience on mental health and life satisfaction. Iranian Journal of psychiatry and clinical psychology. 2007; 13(3):290-5. [Persian]

31. Yadollahi M, Razmjooei A, Jamali K, Niakan MH, Ghahramani Z. The relationship between professional quality of life (ProQol) and general health in Rajaee Trauma Hospital staff of Shiraz, Iran. Shiraz E-Medical Journal. 2016; 17(9). [Persian]

32. Vagharseyyedin SA, Zarei B, Hosseini M. The role of workplace social capital, compassion satisfaction and secondary traumatic stress in affective organisational commitment of a sample of Iranian nurses. J Res Nurs. 2018; 23(5):446-56. 
33. Yang Y-H, Kim J-K. A literature review of compassion fatigue in nursing. Korean Journal of Adult Nursing. 2012; 24(1):38-51.

34. Ebrahimpour M, Azzizadeh Forouzi M, Tirgari B. The relationship between post-traumatic stress symptoms and professional quality of life in psychiatric nurses. Journal of hayat. 2017;22(4):31224. [Persian]

35. Mangoulia P, Fildissis G, Koukia E, Alevizopoulos G, Katostaras T. Factors associated with compassion fatigue among ICU nurses in Greece. Crit Care. 2011; 15(1):P489.

36. Abendroth M, Flannery J. Predicting the risk of compassion fatigue: A study of hospice nurses. $J$ Hosp Palliat Nurs. 2006;8(6):346-56.

37. Yoder EA. Compassion fatigue in nurses. Appl Nurs Res. 2010; 23(4):191-7.

38. Mendes A. Recognising and combating compassion fatigue in nursing. $\mathrm{Br} J$ Nurs. 2014;23(21):1146.

39. Khaghanizadeh M, Ebadi A, Rahmani M. The study of relationship between job stress and quality of work life of nurses in military hospitals. Journal Mil Med. 2008; 10(3):175-84. [Persian]

40. Reyasi H. Work life quality of nurses working in educational hospitals affiliated to Birjand University of Medical Sciences, 2012. Mod Care J. 2013; 10(1):84-90. [Persian]

41. Moradi T, Maghaminejad F, Azizi-Fini I. Quality of working life of nurses and its related factors. Nurs Midwifery stud. 2014; 3(2):1-6.

42. Salimi S, Pakpour V, Feizollahzadeh H, Rahmani A. Resilience and its association with the intensive care unit nurses' intention to leave their profession. Journal of hayat. 2017;23(3):254-65. [Persian]

43. Shakerinia I, Mohammadpour M. Relationship between job stress and resiliency with occupational burnout among nurses. Journal of Kermanshah University of Medical Sciences (J Kermanshah Univ Med Sci). 2010;14(2):161-9. [Persian]

44. Amini F. Comparative analysis of life satisfaction, resilience and burnout among intensive and other units nurses. Quarterly Journal of Nursing Management. 2013; 1(4):9-17. [Persian]

45. Lee KJ, Forbes ML, Lukasiewicz GJ, Williams T, Sheets A, Fischer K, et al. Promoting staff resilience in the pediatric intensive care unit. Am J Crit Care. 2015; 24(5):422-30.

46. Warelow P, Edward Kl. Caring as a resilient practice in mental health nursing. Int J Ment Health Nurs. 2007; 16(2):132-5.

47. Menezes VdLC, Fernández BC, Hernández LM, Ramos FC, Contador IC. Resilience and the burnout-engagement model in formal caregivers of the elderly. Psicothema. 2006; 18(4):791-6.

48. Edward K-l, Hercelinskyj G. Burnout in the caring nurse: learning resilient behaviours. $\mathrm{Br} J \mathrm{Nurs}$. 2007; 16(4):240-2.

49. Dyer JG, McGuinness TM. Resilience: Analysis of the concept. Arch Psychiatr Nurs. 1996; 10(5):276-82. 